\title{
Homeless During Past Year
}

National Cancer Institute

\section{Source}

National Cancer Institute. Homeless During Past Year. NCI Thesaurus. Code C102645.

An individual without a stable or permanent residence within the last 365 days. 